This item was submitted to Loughborough's Research Repository by the author.

Items in Figshare are protected by copyright, with all rights reserved, unless otherwise indicated.

\title{
Workplace parking levies: the answer to funding large scale local transport improvements in the UK?
}

\section{PLEASE CITE THE PUBLISHED VERSION}

http://dx.doi.org/10.1016/j.retrec.2014.09.068

\section{PUBLISHER}

(c) Elsevier

\section{VERSION}

SMUR (Submitted Manuscript Under Review)

\section{PUBLISHER STATEMENT}

This work is made available according to the conditions of the Creative Commons Attribution-NonCommercialNoDerivatives 4.0 International (CC BY-NC-ND 4.0) licence. Full details of this licence are available at: https://creativecommons.org/licenses/by-nc-nd/4.0/

\section{LICENCE}

CC BY-NC-ND 4.0

\section{REPOSITORY RECORD}

Dale, Simon, Matthew W. Frost, Stephen G. Ison, and Peter Warren. 2019. "Workplace Parking Levies: The Answer to Funding Large Scale Local Transport Improvements in the UK?". figshare. https://hdl.handle.net/2134/17632. 


\title{
Workplace Parking Levies: the answer to funding large scale local transport improvements in the UK?
}

\section{Workshop 7 - Innovative Finance for Innovative Public Transport}

\author{
Authors: Mr Simon Dale ${ }^{\mathrm{a}, \mathrm{b}}$, , Dr Matthew Frost ${ }^{\mathrm{a}}$, Prof. Stephen Ison ${ }^{\mathrm{a}}$ and Mr Peter \\ Warren ${ }^{\mathrm{b}}$ \\ ${ }^{a}$ Centre for innovative and Collaborative Construction Engineering, School of Civil and Building Engineering, Loughborough \\ University, UK \\ ${ }^{\mathrm{b}}$ Nottingham City Council, UK \\ * Corresponding author: Centre for innovative and Collaborative Construction Engineering, Loughborough University \\ Loughborough, Leicestershire, UK LE113TU +447795055149, s.dale@lboro.ac.uk
}

Presenting author: Mr Simon Dale, Student, Centre for innovative and Collaborative Construction Engineering, Loughborough University, UK s.dale@lboro.ac.uk

Key Words: Hypothecation, Parking, Levy, Workplace, Funding

\begin{abstract}
Despite positive experiences in Australia of utilising area wide workplace parking place charges to pay for public transport improvement, only one UK local authority, to date, Nottingham City Council has chosen to implement a Work Place Parking Levy scheme (WPL). This scheme intends to allocate the revenue raised to fund (amongst other things) two new tram lines.
\end{abstract}

Acceptance by the public and the business community are seen as key barriers to implementing a WPL. The two major criticisms of the Nottingham scheme prior to its implementation were that a WPL would discourage business investment and thus damage the economy while its intended impact on traffic congestion would be minimal.

Therefore a detailed assessment of the Nottingham WPL scheme's performance is essential in order to facilitate transferability of this approach to other UK and European Cities and thus bring WPL into the mainstream for funding transport improvements.

This paper outlines the barriers to implementation of the Nottingham WPL scheme, and the rationale behind the chosen use of revenue and how the scheme's performance will be evaluated as a transport demand management measure, as well as some initial performance monitoring data following the first year of operation.

The results to date are discussed with a view to identifying any early indications as to whether traffic congestion and business investment has been impacted by the scheme's introduction.,.

\section{Introduction}

Currently both Road User Charging and Workplace Parking Levies are available to Local Authorities in the UK as instruments for raising revenue. Any revenue raised must, by law, be used to fund transport improvements. This hypothecation of such revenue is not a new idea, indeed it was used in the UK in the late 1800s when the Road Fund Licence (Later to become the Vehicle Excise Duty) was used to finance road construction. (Ison and Mulley 2013). 
This paper will consider to what extent current data suggests that a Work Place Parking Levy is the answer to funding large scale public transport improvements in the UK. This will be facilitated by briefly considering the performance of similar Parking Space Levies in operation in Australia and by examining the only scheme currently in operation in the UK, in Nottingham, in terms of its objectives, barriers to implementation and the data that is currently available to measure progress towards these objectives.

The background to the WPL scheme in Nottingham is covered, the current literature relevant to hypothecation of funding for transport schemes, how the hypothecated funding from the Nottingham WPL scheme will be spent and barriers that mitigate against the introduction of WPL schemes in the UK. The paper concludes by outlining the monitoring framework for the WPL including objectives, relevant indicators and data collection methodologies before drawing conclusions based on current data as to how the Nottingham WPL scheme is performing after its first year of full operation.

\section{Background}

Nottingham is one of 9 English core cities, situated $180 \mathrm{~km}$ north of London it is the largest conurbation in the East Midlands with a population of 670,000 . Figure 1 shows its location and principal transport links. With a smaller population of 304,000, the Nottingham City Council administrative area covers the central area of the city only with the urban suburbs of Beeston, West Bridgford, Hucknall, Gedling and Arnold lying in the surrounding boroughs.

Nottingham has long experienced peak period traffic congestion which it is estimated costs the economy £166 million per year (NCC 2013). A population growth of around 9\% over a 15 year period from 2011 is also expected (NCC 2013) It is thus not surprising that tackling congestion by promoting sustainable transport choices is at the heart of the City Council's transport policy. A central pillar of this approach has been the introduction of a Workplace Parking Levy with the dual purpose of acting as a transport demand management tool in its own right as well as funding large scale public transport improvements. The Nottingham Workplace Parking Levy (WPL) scheme uses the provisions of the UK Transport Act 2000 and the subsequent Workplace Parking Levy (England) Regulations 2009 to levy a charge on occupied private non domestic off street parking spaces i.e. Workplace Parking Places (WPP) occupied by employees, regular business visitors or students. The WPL covers only the Nottingham City Council administrative area and currently the charge per WPP is £334 per year. This charge will rise at above the rate of inflation until 2015, there after it will rise at the rate of inflation. This 'escalator' is intended to coincide with the completion of the public transport improvements supported by the scheme. Employers apply for a licence for each of their premises (where parking places are provided) which states the number of WPP they wish to use and then pay the appropriate Levy.

The following are exempt from this charge or receive a $100 \%$ discount:

- Premises from which frontline health services are provided by or on behalf of the NHS.

- Premises occupied by the emergency services.

- Places occupied by customers, disabled blue badge holders and delivery vehicles.

- Employers with 10 or fewer WPP.

Licensing was introduced in October 2011 and charging commenced six months later on the $1^{\text {st }}$ April 2012. 
Figure 1 Nottingham Conurbation and its major transport links

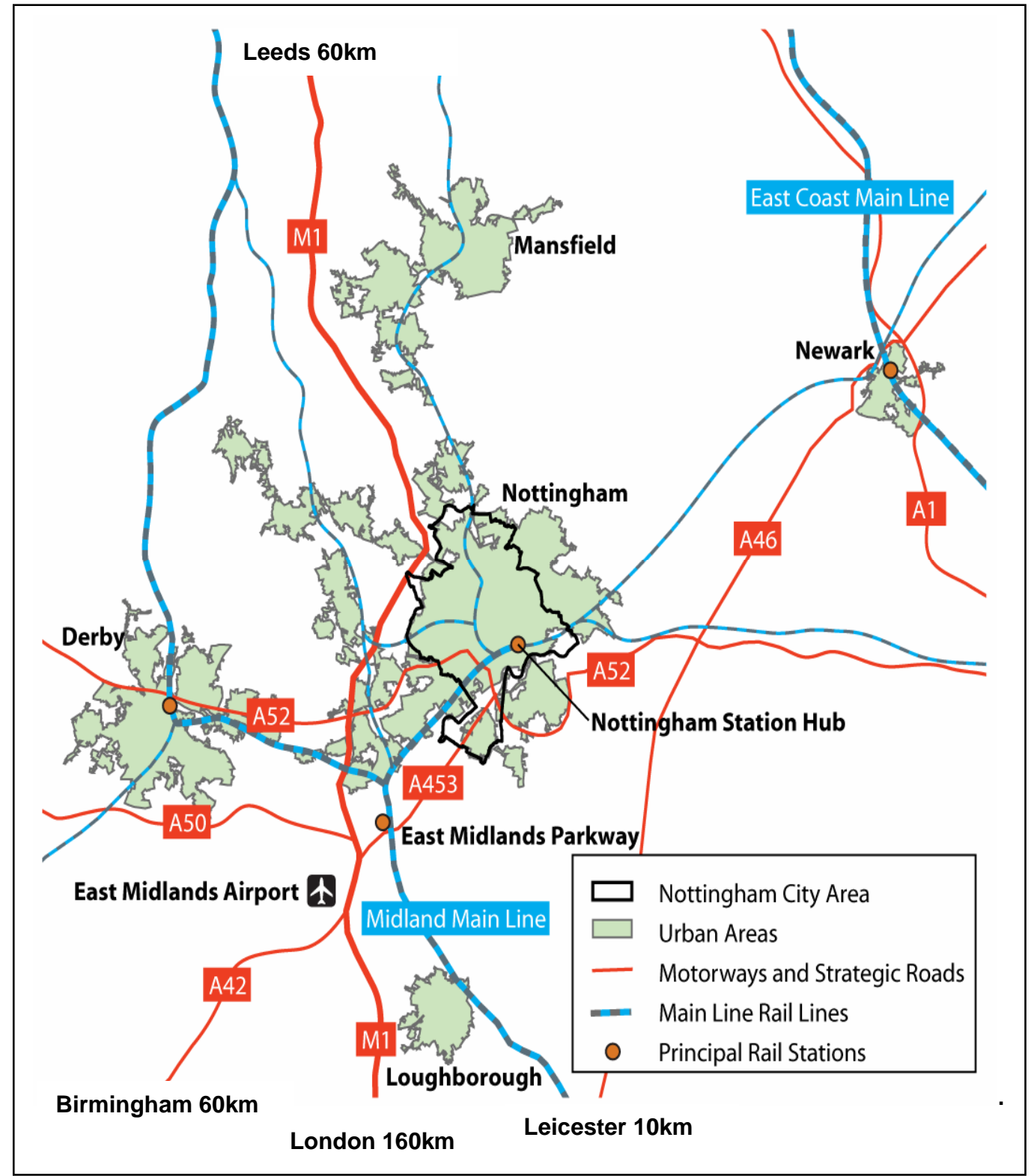

Source: Nottingham City Council.

The revenue raised by the WPL will be used to part fund a package of transport improvements which include Nottingham Express Transit Phase 2 (two new tram lines), improvements to Nottingham Railway Station and Linkbus services to connect between the tram corridors.

To date Nottingham is the only UK city to introduce a Workplace Parking Levy (Frost and Ison 2008), and it was recognised by the City Council that tracking the scheme's performance would play an important part in its transferability to other Cities. Thus the 2008 Business Case for the Nottingham WPL (NCC 2008) included the expectation that the performance of the scheme would be monitored against a broad set of objectives.

Although a WPL is a legally binding levy and thus will be an effective mechanism for raising hypothecated funding for transport improvements, its overall success will be dependent on its ability to gain acceptance by the public and the business community as well as co-existing with other important policy objectives. If these conditions are not satisfied then history suggests that the schemes could be short-lived and that it could prove politically 
unacceptable for other cities to introduce a similar scheme. An example of such a failure can be seen in Vancouver which experimented with charging a levy on parking. This levy was based on a charge on parking surface area per square metre. Although this was introduced in 2006, heavy opposition from business prompted a re-think and it was quickly replaced by a tax on transactions for paid parking (Litman 2011). With this lesson and considering the demise of other unpopular taxes, (such as the community charge (poll tax) in the UK), six scheme objectives were developed by Nottingham City Council to fit a broad policy agenda as well as a revenue raising aim.

These objectives are based on the 2008 Business Case and its subsequent review from the "Examination in Public" (Dodd 2007) and are summarised in Table 1.

Therefore, for the WPL to become a mainstream option for funding public transport in the UK, the scheme in Nottingham will need to demonstrate that it can both raise revenue as well as gain acceptance and complement other policy objectives.

\section{Literature Review}

This section examines the literature regarding the nature of hypothecation and the characteristics and effectiveness of existing parking space levy schemes

\section{What is Hypothecation?}

Hypothecation can be defined as the allocation of particular tax revenues to specific areas of government spending (Ison and Mulley 2013).

In Australia there are examples of revenue from parking charges being hypothecated for transport improvements in both Perth and Sydney. In Perth the revenue has been used to provide a Central Area Transit bus system and expansion of the Free Transit Zone (Enoch 2001), while in Sydney the revenues have been spent mostly on commuter car parks and interchanges (Ison and Mulley,2013).

In general hypothecation has the advantage that it provides a stable revenue stream for a given purpose (Deran 1965), especially in the case of levies on property which the WPL essentially is. It also has the advantage that clearly identifying the use of a tax or levy can be more acceptable to those that pay it (Ison and Mulley 2013).

Deran (1965) explained a number of limitations to hypothecation, these mostly referred to the inherent lack of flexibility for policy makers to switch the funding to alternate purposes when 'over funding occurs' or indeed when policy priorities change. However, it has to be considered that if the legislative description of a potential use of the revenue is sufficiently broad then these criticisms should be offset. There is a case that hypothecation for "transport improvements" is highly unlikely to result in over funding, and such funding is always likely to be an important policy area. 


\begin{tabular}{|c|c|c|}
\hline \multicolumn{3}{|c|}{ Table 1 The Workplace Parking Levy Monitoring Framework Adapted from Nottingham City Council 15/05/2013 } \\
\hline Nottingham WPL Objective & Performance Indicators & Metrics to be used to monitor indicator \\
\hline \multirow[t]{10}{*}{ Objective 1: Constrain congestion in the AM and PM peak periods } & Congestion (Car Journey Times) & AM peak period journey time per vehicle mile (dec \\
\hline & \multirow[t]{2}{*}{ Area-wide traffic mileage } & Millions of vehicle miles p.a. in Nottingham City \\
\hline & & Millions of vehicle miles p.a. in Greater Nottingham \\
\hline & Single occupancy car journeys & $\begin{array}{l}\text { \% of single occupancy cars against multi occupancy cars observed at Inner Traffic Area } \\
\text { Cordon mode share sites in AM peak period }\end{array}$ \\
\hline & \multirow[t]{6}{*}{ Bus services running on time } & Excess waiting time for frequent services in City \\
\hline & & Excess waiting time for frequent services in Greater Nottingham \\
\hline & & $\%$ of non frequent buses on time at timing points in City, \\
\hline & & $\%$ of non frequent buses on time in Greater Nottingham \\
\hline & & $\%$ of buses starting on time in City \\
\hline & & $\%$ of buses starting on time in City \\
\hline \multirow{3}{*}{$\begin{array}{l}\text { Objective 2: Increase uptake of workplace travel plans \& responsible parking } \\
\text { management strategies }\end{array}$} & $\%$ of employees covered by a travel plan & Percentage of employees covered by a travel plan \\
\hline & $\begin{array}{c}\text { Number of places and number of employers covered by workplace } \\
\text { parking management schemes }\end{array}$ & $\begin{array}{l}\text { Number of workplace parking places (WPP) and employers covered by parking } \\
\text { management schemes }\end{array}$ \\
\hline & Take-up of support packages number by type & $\begin{array}{l}\text { Number of employers taking up travel planning or parking, management support } \\
\text { packages }\end{array}$ \\
\hline \multirow[t]{4}{*}{$\begin{array}{l}\text { Objective 3: Contribute to the implementation of major transport schemes and the } \\
\text { Local Transport Plan. }\end{array}$} & Net WPL Revenue & $\begin{array}{l}\text { Total Revenue (£) minus operating costs, business support and traffic management } \\
\text { expenditure }\end{array}$ \\
\hline & $\begin{array}{l}\text { City Council WPL operating costs including business support and traffic } \\
\text { management costs }\end{array}$ & Expenditure on business support and traffic management $(\mathcal{E})$ \\
\hline & City Council WPL operating costs & Operating costs $(£)$ \\
\hline & $\begin{array}{l}\text { Number of WPP places, premises and employers covered by each } \\
\text { exemption/discount }\end{array}$ & Total number of exempt WPPs excluding those occupied by disabled Blue Badge holders \\
\hline \multirow[t]{6}{*}{ Objective 4: Encourage sustainable travel and mode choice } & $\begin{array}{l}\text { Mode share of public transport at Inner Area Traffic Cordon in AM peak } \\
\text { period }\end{array}$ & $\%$ of travel by public transport on main radial routes + rail \\
\hline & Local bus and light rail passenger journeys & Millions of passengers on trams and buses in City \\
\hline & & Millions of passengers on trams and buses in Greater Nottingham \\
\hline & Cycling trips & Cycle counts at strategic points in City \\
\hline & Mode of journeys to school & Proposed "Hands up survey" at schools TBC \\
\hline & Single occupancy car journeys & $\begin{array}{l}\text { \% of single occupancy cars observed at Inner Traffic Area Cordon mode share sites in AM } \\
\text { peak period }\end{array}$ \\
\hline \multirow{2}{*}{$\begin{array}{l}\text { Objective 5: Enhance the attractiveness of Nottingham as a location for business } \\
\text { investment. }\end{array}$} & Employee numbers (or similar indicators from City Economic Review) & Number of jobs in the City \\
\hline & Business location decisions & Research Project TBC \\
\hline Objective 6: No significant displaced parking problems & $\begin{array}{l}\text { Displaced parking analysis, number of complaints, number of schemes } \\
\text { by type , cost of schemes }\end{array}$ & Number of WPL related complaints per year \\
\hline
\end{tabular}




\section{Existing parking place levies and their effectiveness}

Table 2 summarises the characteristics of five similar parking levy schemes. however, not all shopping and leisure trips.

From Table 2 we can see that Nottingham is the most restricted in the type and use of places upon which a charge is made. Nottingham has opted to charge only occupied places supplied to employees, students or regular business visitors by employers i.e. public on street or off street parking and customer parking is not chargeable. The annual charge is lowest in Nottingham while Sydney is the highest. All four current schemes have similar exemptions based on type of use.

However important differences occur between the schemes with respect to how small businesses are charged. Nottingham has opted to exempt small businesses by giving those with 10 or fewer chargeable workplace parking places a $100 \%$ discount. This goes further than the similar exemption offered by Perth, while Sydney and Melbourne offer no such concessions. Despite the city wide nature of the Nottingham WPL, the above factors make the annual revenue from the Nottingham scheme much lower than its Australian counterparts.

All five schemes are primarily aimed at targeting traffic congestion via both the pricing element as well as investment of the revenue raised into public transport infrastructure.

Nottingham's more timid approach to the annual charge and exemptions for small businesses could be attributed to the proximity of competitor cities close by while a city like Perth is isolated from its competitors. However this may also reflect cultural and political differences.

\section{Effectiveness of existing parking place levy's}

Richardson (2010) studied the outcome of the Perth scheme. He reports that following its introduction, parking supply contracted by $10 \%$ before slowly rebounding but not recovering to pre 1999 levels. This reverses the pre 1999 trend of steadily increasing parking supply.

Clearly a reduction in workplace parking supply is not a guarantee that congestion will decrease. However Richardson (2010) presents figures from the Australian Bureau of Statistics for Perth which show that there has been a significant shift in modal share. Prior to implementation only 35\% of journeys to work were by public transport; however by 2010 this had risen to over $50 \%$, while car modal share had fallen by a similar amount clearly demonstrating a modal shift to public transport. Indeed public transport use has grown by $67 \%$ in the 10 years from 1999 to 2009.

Richardson reports that the volume of car traffic on radials providing access to the city reduced by between $3 \%$ and $20 \%$ in the three years following implementation of the scheme and that traffic within the city has continued to decline.

It is important to note that, over a decade after the introduction of the Perth Parking Licence Fee, Perth is still struggling to address traffic congestion due to a booming economy with a large increase in population (Martin, 2012). It should be noted that in the media and public debate in both 
Table 2: Summary of area wide parking place levy schemes. Sources: NCC (2008), NCC( 2012), Enoch (2001), Richardson (2010), Hamer et al (2009), Translink (2012), State Revenue Office Victoria (2012), Transport for NSW (2013), DoT (2012) and Litman (2011).

\begin{tabular}{|c|c|c|c|c|c|c|c|c|c|c|c|c|}
\hline \multirow[t]{2}{*}{ Location } & \multirow[t]{2}{*}{ Area } & \multicolumn{5}{|c|}{ What's Liable for charge } & \multirow[t]{2}{*}{ Introduced } & \multirow[t]{2}{*}{ Main Exemptions } & \multirow{2}{*}{$\begin{array}{l}\text { Approx } \\
\text { annual } \\
\text { revenue }\end{array}$} & \multirow{2}{*}{$\begin{array}{l}\text { Charge per } \\
\text { place }\end{array}$} & \multirow[t]{2}{*}{ Objectives } & \multirow[t]{2}{*}{ Uses Of Revenue } \\
\hline & & $\begin{array}{l}\text { General } \\
\text { Description }\end{array}$ & $\begin{array}{l}\text { On } \\
\text { Street } \\
\text { Parking }\end{array}$ & $\begin{array}{l}\text { Public } \\
\text { Car } \\
\text { Parks }\end{array}$ & $\begin{array}{l}\text { Un } \\
\text { occupied } \\
\text { Spaces }\end{array}$ & $\begin{array}{l}\text { Small } \\
\text { Business }\end{array}$ & & & & & & \\
\hline $\begin{array}{l}\text { Perth - } \\
\text { Parking } \\
\text { Licence Fee }\end{array}$ & $\begin{array}{l}\text { Central } \\
\text { Business } \\
\text { District } \\
\text { (CBD) }\end{array}$ & $\begin{array}{l}\text { All non } \\
\text { residential } \\
\text { parking bays } \\
\text { that are in use }\end{array}$ & YES & YES & NO & NO & 1999 & $\begin{array}{l}\text { Disabled spaces } \\
\text { Loading Bays } \\
\text { Pubic service bays } \\
\text { Businesses }<6 \text { space } \\
\text { Spaces incidental to } \\
\text { primary business activities }\end{array}$ & $30 \mathrm{~m}$ & $\begin{array}{l}\text { Long Stay: } \\
\text { A } \$ 630 \text {, } \\
\text { Short Stay: } \\
\text { A } \$ 600 \\
(2012)\end{array}$ & $\begin{array}{l}\text { Cut congestion by } \\
\text { effecting modal } \\
\text { shift and fund } \\
\text { Central Area } \\
\text { Transit bus system }\end{array}$ & $\begin{array}{l}\text { Hypothecated for } \\
\text { transport } \\
\text { CAT bus system } \\
\text { Free transit zone }\end{array}$ \\
\hline $\begin{array}{l}\text { Sydney - } \\
\text { Parking } \\
\text { Space Levy } \\
\text { (PSL) }\end{array}$ & $\begin{array}{l}\text { CBD + five } \\
\text { other } \\
\text { outlying } \\
\text { business } \\
\text { areas }\end{array}$ & $\begin{array}{l}\text { Off street } \\
\text { private non } \\
\text { residential } \\
\text { parking, } \\
\text { occupied or un- } \\
\text { occupied, does } \\
\text { not apply to } \\
\text { public car } \\
\text { parks. }\end{array}$ & NO & NO & YES & YES & 1992 & $\begin{array}{l}\text { Disabled spaces } \\
\text { Loading Bays } \\
\text { Pubic service bays } \\
\text { Spaces incidental to } \\
\text { primary business activities } \\
\text { Retail, restaurant, hotel } \\
\text { parking, etc in outlying } \\
\text { areas }\end{array}$ & $97 \mathrm{~m}$ & $\begin{array}{l}\text { A\$2100 } \\
\text { CBD and } \\
\text { North } \\
\text { Sydney, } \\
\text { A } \$ 740 \text { in } \\
\text { other areas } \\
\text { (2011) }\end{array}$ & $\begin{array}{l}\text { Discourage car use } \\
\text { Fund infrastructure to } \\
\text { encourage public } \\
\text { transport use }\end{array}$ & $\begin{array}{l}\text { Hypothecated for } \\
\text { public transport. } \\
\text { Interchanges, } \\
\text { bus/rail/ferry. } \\
\text { Park and Ride. } \\
\text { Rapid bus only transit } \\
\text { way. } \\
\text { Light rail. } \\
\text { Electronic passenger } \\
\text { information system. }\end{array}$ \\
\hline $\begin{array}{l}\text { Melbourne } \\
- \\
\text { Congestion } \\
\text { Levy }\end{array}$ & CBD & $\begin{array}{l}\text { All public and } \\
\text { private long } \\
\text { stay non } \\
\text { residential car } \\
\text { parking spaces } \\
\text { currently in use }\end{array}$ & NO & YES & NO & YES & 2006 & $\begin{array}{l}\text { Business visitors. } \\
\text { Emergency vehicles. } \\
\text { Council and charities. } \\
\text { Shift workers. } \\
\text { Spaces incidental to } \\
\text { primary business activities. }\end{array}$ & & $\begin{array}{l}\mathrm{A} \$ 930 \\
(2013)\end{array}$ & $\begin{array}{l}\text { Reduce Congestion } \\
\text { by encouraging } \\
\text { commuters to use } \\
\text { public transport. } \\
\text { Create more parking } \\
\text { for shoppers and } \\
\text { visitors. } \\
\end{array}$ & $\begin{array}{l}\text { Not hypothecated but } \\
\text { some revenue is used } \\
\text { for public transport } \\
\text { improvements. }\end{array}$ \\
\hline $\begin{array}{l}\text { Vancouver } \\
\text { - Parking } \\
\text { Site Tax }\end{array}$ & $\begin{array}{l}\text { Greater } \\
\text { Vancouver }\end{array}$ & $\begin{array}{l}\text { Non residential } \\
\text { parking areas. } \\
\text { Charged by } \\
\text { area size. }\end{array}$ & NO & YES & YES & YES & $2006-2007$ & $\begin{array}{l}\text { Buildings not subject to } \\
\text { property tax. } \\
\text { Translink Properties } \\
\text { Spaces incidental to } \\
\text { primary business activities. }\end{array}$ & $\mathrm{NA}$ & $\begin{array}{l}\$ 1.02 \text { per } \\
\text { square } \\
\text { meter }(2006) \\
\text { (approx } \$ 32 \\
\text { per space) }\end{array}$ & $\begin{array}{l}\text { Used to fund } \\
\text { Translink, } \\
\text { Vancouver, British } \\
\text { Columbia Transport } \\
\text { Authority. }\end{array}$ & $\begin{array}{l}\text { Expansion of road and } \\
\text { transit system. }\end{array}$ \\
\hline $\begin{array}{l}\text { Nottingham } \\
- \\
\text { Workplace } \\
\text { Parking } \\
\text { Levy }\end{array}$ & $\begin{array}{l}\text { City of } \\
\text { Nottingham }\end{array}$ & $\begin{array}{l}\text { Occupied } \\
\text { private non } \\
\text { residential off } \\
\text { street } \\
\text { workplace } \\
\text { parking }\end{array}$ & NO & $\mathrm{NO}$ & NO & $\mathrm{NO}$ & 2011 & $\begin{array}{l}\text { Customers. } \\
\text { Emergency Services. } \\
\text { Disabled Spaces } \\
\text { Loading Spaces } \\
\text { Employers with < } 11 \\
\text { spaces. } \\
\text { NHS or NHS Contractors } \\
\text { delivering frontline } \\
\text { services. }\end{array}$ & $£ 7 \mathrm{~m}$ & $£ 334(2013)$ & $\begin{array}{l}\text { Constrain } \\
\text { Congestion. } \\
\text { Encourage modal } \\
\text { shift to more } \\
\text { sustainable modes. } \\
\text { Fund transport infra } \\
\text { structure. }\end{array}$ & $\begin{array}{l}\text { Hypothecated for } \\
\text { transport. } \\
\text { Light rail expansion. } \\
\text { Linkbus Services. } \\
\text { Redevelopment of } \\
\text { Nottingham Railway } \\
\text { Station. }\end{array}$ \\
\hline
\end{tabular}


Perth and Nottingham this continued congestion has been used to suggest the scheme have been ineffective. However the literature suggests that the Perth Parking Levy has affected both modal shift and an initial drop in traffic levels. The issue is that this is being obscured by continued economic growth, which has led to further congestion which if not combated may have had its own constraining affect.

Hamer et al (2009) carried out a review of the outcomes from the Melbourne Central Business District (CBD) parking levy. They used census data and data from household questionnaire surveys to quantify changes to the number and nature of trips, i.e. travel demand. This was split between all trip purposes and commuter trips and within these trips those that terminated in off street car parks within the CBD.

They conclude that the data revealed that although the total number of trips to the CBD had remained stable, the number and proportion of cars entering the charging area has fallen. However they conclude that the levy is having only a minor impact on congestion.

The WPL is perceived as an additional cost by businesses (Burchell and Ison 2012) and there is a concern that this will lead to a potentially negative impact on Nottingham especially with reference to Inward Investment (NCC 2005). However the extra WPL cost needs to be understood in the context of a city's overall offer which includes the transport infrastructure and public transport provision (Smyth and Christodoulou 2010). Nottingham City Council believes that the overall offer will be sufficiently enhanced by public transport improvements that the WPL package will deliver that this will offset the perceived deterrent effect on investment of the additional cost of WPL (NCC 2008.

A study commissioned by Core Cities, Passenger Transport Executive Group and Yorkshire Forward and carried out by GVA Grimley (Core Cities et al 2006) examined the competitiveness of Manchester, Birmingham and Leeds by carrying out detailed face to face and telephone interviews with businesses. The results were considered to be transferable to other English Core Cities including Nottingham. The results supported Smyth and Christodoulou's (2010) conclusions and the results of the Invest Thames Gateway study in that they revealed that there was a strong view amongst those interviewed that an efficient transport system was a key determinant in business location decisions, but it was perhaps not the most important factor. Smyth et al (2010a) and the Core Cities (2006) both conclude that an efficient transport system can be considered an important prerequisite for business location.

The Core Cities study also revealed that many respondents described themselves as "footloose" i.e. if their location became less attractive they could move quite easily. The relative propensity of footloose, cost sensitive businesses to be discouraged by the additional cost of WPL (NCC 2005) combined with this finding is an area of concern for Nottingham as it attempts to sell WPL to its indigenous business population.

Here in perhaps lies an "unknown" in business location research - Clearly business values high quality transport networks but is it prepared to pay through an additional tax.

Transport for London (TfL 2008), used the level of VAT registrations and de-registrations as the principal metric for assessment of the level of business investment. They compared net annual change of this in the Central Zone pre and post implementation of the London Congestion Charge along with figures for outer London. Based on this they concluded that there is no evidence that charging has impacted on the level of investment in the central charging area. However, London is a special case due to its size and current infrastructure. 
In Perth, Australia, the following objective was set out in the Perth Parking Policy 2012; "Ensuring the continued economic and social vitality of central Perth;" (State of Western Australia, 2012). Richardson (2010) reported that concerns expressed that the levy would act contrary to that objective cannot be supported. Richardson evidences this statement by observing that both floor space and employment have enjoyed strong growth.

While data from Perth and London suggest that there is no evidence that congestion charging has produced a negative impact on business investment applying these conclusions to Nottingham is of limited value as both the nature of the charging schemes and the status and proximity of competitor cities are different. It can be speculated that Nottingham would be more vulnerable to adverse effects of congestion charging on business as it has competitor cities close by.

The limited literature on WPLs suggests that it is primarily seen as a revenue raising tool with a secondary effect as a TDM Tool in its own right. However when this revenue is reinvested in the provision of public transport alternatives, evidence from Australia where parking charges have been implemented in Perth, Sydney and Melbourne, suggest that a WPL package can be effective in achieving significant modal shift.

\section{The use of hypothecated funding from the Nottingham WPL.}

In the UK it is mandatory for each local authority to produce a Local Transport Plan (LTP) and submit it to the Department for Transport in order to receive a share of the funding available from central government. An LTP presents the transport strategy and the plan for implementing that strategy. The schemes in the LTP are summarised in Table 3.

Table 3: Issues tackled by programmed major transport schemes in Nottingham

\begin{tabular}{|l|l|l|}
\hline Intervention & Description & Issues addressed by scheme \\
\hline $\begin{array}{l}\text { Werkplace Parking } \\
\text { Levy }\end{array}$ & $\begin{array}{l}\text { Levy payable by employers on parking } \\
\text { places provided to employees, regular } \\
\text { business visitors and students, }\end{array}$ & $\begin{array}{l}\text { Constrain Congestion by increasing the cost } \\
\text { of commuting to work by car, help provide } \\
\text { funding for public transport improvements }\end{array}$ \\
\hline $\begin{array}{l}\text { Nottingham Express } \\
\text { Transit Phase 2 } \\
\text { Chilwell and Clifton linked to the central } \\
\text { public transport hub at Nottingham } \\
\text { Station }\end{array}$ & $\begin{array}{l}\text { Constrains peak period congestion and } \\
\text { enhance transport connectivity, } \\
\text { Provision for future growth }\end{array}$ \\
\hline $\begin{array}{l}\text { Regeneration of } \\
\text { Statingham Rail }\end{array}$ & $\begin{array}{l}\text { Refurbish Nottingham Station to provide } \\
\text { high quality public transport hub }\end{array}$ & $\begin{array}{l}\text { Transport Connectivity to other cities and } \\
\text { international and national gateways }\end{array}$ \\
\hline $\begin{array}{l}\text { Ring Road Major } \\
\text { Scheme }\end{array}$ & $\begin{array}{l}\text { Improvements to junctions to ease } \\
\text { congestion and improved public transport } \\
\text { interchanges along the Ring Road }\end{array}$ & Congestion, local connectivity \\
\hline $\begin{array}{l}\text { Provision of Link } \\
\text { Buses }\end{array}$ & $\begin{array}{l}\text { Provide high quality link bus services } \\
\text { between the tam corridors }\end{array}$ & $\begin{array}{l}\text { Congestion, local connectivity } \\
\text { *A453 Dualing }\end{array}$ \\
$\begin{array}{l}\text { Convert the link road from junction 24 of } \\
\text { the M1 to dual carriageway }\end{array}$ & $\begin{array}{l}\text { Transport Connectivity to other cities and } \\
\text { international and national gateways, } \\
\text { Provision for future growth }\end{array}$ \\
\hline
\end{tabular}

*the A453 scheme is a Highways Agency trunk road funded scheme but is supported by Nottingham City Council.

Based on the rationale presented in the Nottingham LTP it is possible to summarise the issues which are drivers for investment in public transport in Nottingham (NCC 2013):

1. Congestion: The City Council estimates, that peak period congestion costs the city economy £166 million a year and is particularly acute on key radial routes

2. Connectivity: The City council believes that strong connectivity to other urban centres and national and international gateways is essential if Nottingham is to remain competitive as a location to do business. 
3. Significant Growth. The City Council forecasts that the population is set to rise by $9 \%$ over a 15 year period from 2011 driven by a growth in science and technology, knowledge intensive and creative industries.

The Workplace Parking Levy therefore has a dual role to play in the City Council's strategy as it's both a transport demand management tool and a major source of funding. Table 4 presents the cost of each scheme and the contribution made by WPL revenues.

This data shows how the money raised by WPL is leveraged by investment from Central Government. An important benefit in the current economic climate of investing in large scale public transport schemes is that this provides a significant temporary boost to the local economy while they are implemented.

Table 4 Funding of programmed major transport schemes in Nottingham

\begin{tabular}{|l|l|l|l|l|}
\hline Scheme & $\begin{array}{l}\text { Total Cost } \\
\text { (£millions) }\end{array}$ & $\begin{array}{l}\text { NCC “Local” } \\
\text { Contribution } \\
\text { (£millions) }\end{array}$ & $\begin{array}{l}\text { WPL } \\
\text { Contribution } \\
\text { (£millions) }\end{array}$ & Completion date \\
\hline NET Phase 2 & 550 & 150 & 150 & 2014 \\
\hline $\begin{array}{l}\text { Ring Road } \\
\text { Major }\end{array}$ & 16.175 & 3.2 & 0 & 2015 \\
\hline $\begin{array}{l}\text { Provision of } \\
\text { Link Buses }\end{array}$ & 6.59 & 3.05 & 3.05 & On going \\
\hline LTP & 6 per year & 0 & 0 & On going \\
\hline $\begin{array}{l}\text { Refurbishment } \\
\text { of Rail Station }\end{array}$ & 60 & Up to 18 & Up to 14 & 2014 \\
\hline
\end{tabular}

Source: Nottingham City Council 13/06/2013

Figure 2 below shows the financial data pertaining to the WPL scheme. This shows that Nottingham City Council spent $£ 369,243$ to help manage the impact of the WPL on employers and to encourage sustainable transport. This is $5 \%$ of the WPL revenue.

\section{Figure 2 Use of WPL Revenue}

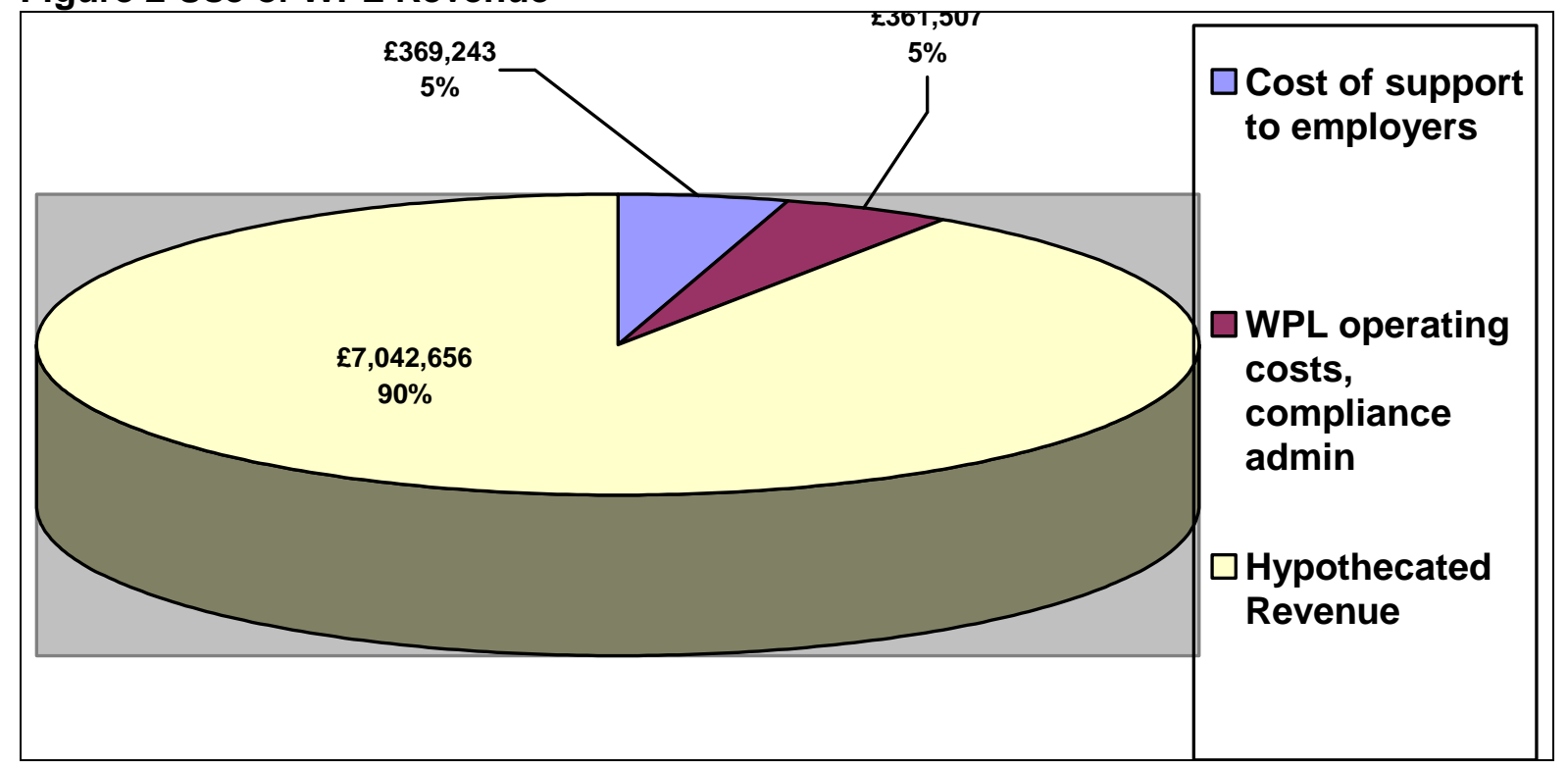

A further $£ 361,507$ is spent on the WPL's operating cost, $5 \%$ of revenue. Figure 2 also reveals that the WPL scheme contributes $90 \%$ of its revenue towards further transport improvements. This can be considered more financially efficient than road user charging schemes and was one of the reasons a WPL was chosen by Nottingham City Council. 
Although the London Congestion Charge raises more money in absolute terms than the WPL as one would expect, it is less efficient with $49 \%$ of revenue taken up by costs

Table 5 below shows a breakdown of how the revenue collected is derived across the different sizes of employers in term of WPP provision. This table shows a comparison between the actual data from the first year of operation and estimate of the number of WPP provided by the Off Street Parking Audit survey (OSPA) in 2010. The number of chargeable places is those WPP provided by employers liable for the charge, as opposed to those subject to exemption or discount. This excludes those occupied by blue badge holders or those provided by employers who are eligible for a $100 \%$ discount.

This illustrates that the largest 42 WPP providers account for $55 \%$ of the revenue but form less than $10 \%$ of liable employers. This is an important consideration as it makes compliance and enforcement easier to target in terms of securing the revenue.

It can also be seen that the supply of WPP has reduced by approximately $18 \%$ from the 2010 estimate. While the methodology used in the OSPA surveys had inherent limitations, notably that it relied on the employers providing accurate figures not on direct observation, it would appear that the WPL has prompted some contraction in parking supply. The puzzle is that this does not appear to have resulted in an immediate reduction in car use or congestion.

Table 5: WPP provision by WPP size bands.

\begin{tabular}{|c|c|c|c|c|c|c|}
\hline \multirow{2}{*}{$\begin{array}{c}\text { Space } \\
\text { Ranges }\end{array}$} & \multicolumn{2}{|c|}{ Pre WPL Estimate } & \multicolumn{2}{|c|}{ 2012/13 Actual figures } & \multirow{2}{*}{$\begin{array}{l}\% \\
\text { Change } \\
\text { in WPP } \\
2010-13\end{array}$} & \multirow[b]{2}{*}{ Revenue } \\
\hline & $\begin{array}{l}\text { Liable } \\
\text { Employers }\end{array}$ & $\begin{array}{l}\text { Chargeable } \\
\text { WPP }\end{array}$ & $\begin{array}{l}\text { Liable } \\
\text { Employers }\end{array}$ & $\begin{array}{l}\text { Chargeable } \\
\text { WPP }\end{array}$ & & \\
\hline$<11$ & 0 & 0 & 116 & 439 & NA & 250409 \\
\hline $11-100$ & 511 & 14502 & 373 & 11480 & -20.8 & 3324463 \\
\hline $\begin{array}{l}101- \\
5000\end{array}$ & 45 & 17723 & 42 & 14545 & -17.9 & 4198534 \\
\hline Total & 556 & 32225 & 531 & 26464 & -17.9 & 7773406 \\
\hline
\end{tabular}

The 2012/13 revenue figures take account of licence variations that came into effect prior to the end of the financial year thus the revenue figure is not always 288 multiplied by the number of chargeable places. Revenue raised within the banding 1-10 is due to these employers $b$

Source: Nottingham City Council 20/05/2013

\section{Barriers to implementation}

The major barrier to the implementation of any congestion charging scheme is that of public acceptance (Frost and Ison 2008) and this is closely linked to the issue of political risk for the decision makers. Evidence from Nottingham City Council's consultation prior to and during the "Examination in Public" and subsequent press coverage, suggests that typically the WPL is criticised on 3 grounds (Dodd 2007, Westcott 2012 and Nottingham Evening Post 2012):

1. Being an additional burden on business and thus damaging to a city's economy.

2. Being in-effective as a tool to combat congestion.

3. Being unfair on the motorist who already carries a high tax burden.

There is little academic literature as to how acceptable the UK general public would find a WPL scheme partly because until recently there hasn't been one and in order to obtain an accurate picture the interviewees would need to understand what one is. However, some research has been carried out to assess business attitudes to a WPL scheme and not 
surprisingly the business community are less than positive (NCC 2005, Burchell and Ison 2012 and Nottingham and Derby Chamber of Commerce 2012).

A survey of key stakeholders, mainly transport policy decision makers, conducted in 1999 (Ison and Wall 2002) showed that they considered peak period congestion and its associated problems to be fairly serious. They also viewed a WPL as one of the least acceptable measures but most effective measures to combat the problem.

A study carried out by Price Waterhouse Cooper (PwC) on behalf of Nottingham City Council (NCC 2005) showed that although WPL charge was likely to be less than $1 \%$ of a businesses turnover, businesses were highly critical of having to bear this cost. $60 \%$ of businesses interviewed by this 2005 study said they would relocate some activities away from Nottingham and more than $50 \%$ said they would reduce planned investment. $66 \%$ felt the levy would not be offset by improvements in public transport. This identifies a contradiction in both the general non specific perception that a high quality transport system is important to business location, and the relatively low percentage of turnover being asked to fund this and the strong re-action of businesses to this cost.

This then leaves a question of what will businesses actually do?

The barrier of acceptability to the business community has been strengthened as a result of the present government's "Red Tape Review" which included a consideration of WPL schemes as below; it stressed the requirement that any future scheme must be acceptable to the business community.

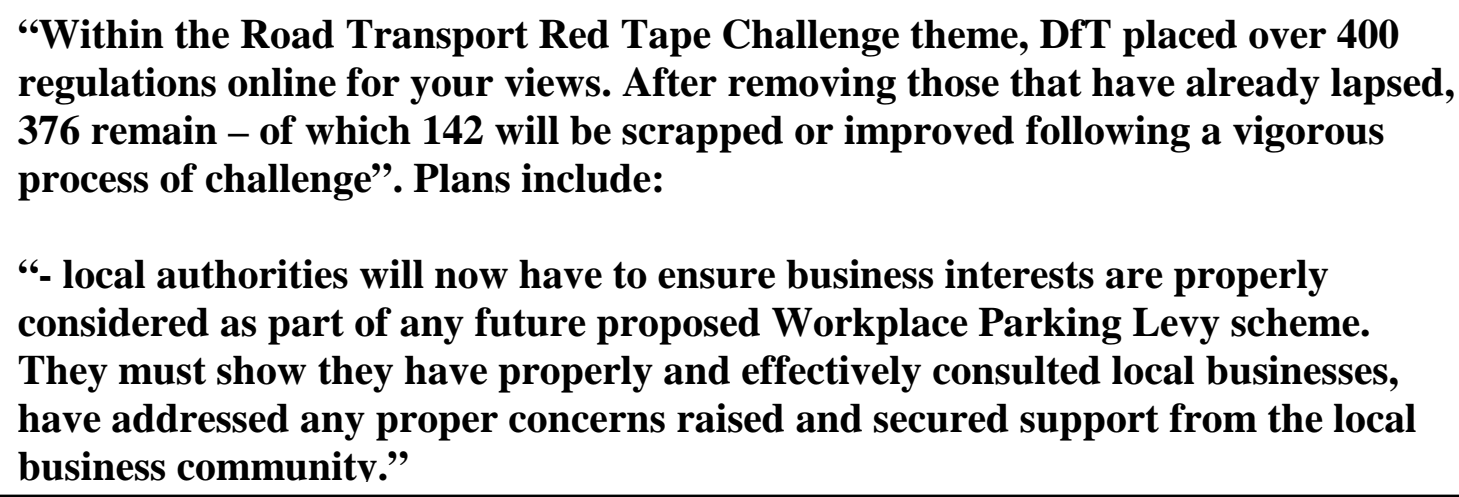

Source: Cabinet Office 2013

Given the evidence of business views presented above this could prove a challenge. Clearly, no local authority wishes to damage the economy of their area and if there is evidence that the presence of the WPL is damaging to the economy in the medium term then the scheme may need re-thinking. However there will be a lag between the introduction of a WPL and the completion of the public transport improvements and some short term "pain" may be acceptable.

The political stability of Nottingham allows decision makers in Nottingham to take a medium to long term view as the decision makers know that they are extremely unlikely to be voted out of office over a single issue such as the WPL provided the economy of the city performs adequately over the medium term. This however is not the case in other similar UK Cities. For example Bristol is more finely balanced politically and politically motivated re-action to an initially unpopular idea can make a big difference electorally. Bristol in the last decade has considered and rejected the idea of a tram scheme, major bus improvements, re-opened rail services and a WPL and one can speculate that this is probably due to political factors rather 
than an objective examination of the pros and cons of such schemes in what is accepted as a congested City.

\section{Evaluating performance; Monitoring framework, methodologies and available data to date.}

\subsection{The monitoring framework}

As stated previously Nottingham City Council has identified 6 key objectives for the WPL scheme (see Table 1). A framework of indicators to measure performance of the scheme against these objectives has been developed.

The paper concentrates on Objectives 1 and 5 relating to congestion and business investment. Based on the discussion in section 5 it is considered that these are the primary objectives in terms of a successful outcome for the WPL scheme and also for its transferability to other cities.

\subsection{Objective 1: Constrain congestion in the AM and PM peak periods}

This is being monitored using the following indicators

- Journey time per vehicle mile (JTVM)

- Area wide traffic mileage

- Bus services running on time

- Percentage of cars with just one occupant

These four indicators combine to give a view as to how congestion in Nottingham changes over time. Only JTVM can be considered as a direct measure of congestion, the other three should be viewed as supporting indicators as they do not necessarily track congestion directly but rather give indications as to whether it is likely to be moving in a positive direction. This is particularly the case with the bus punctuality indicator which is significant in terms of public transport performance, but is not directly related to congestion as recurrent congestion is "built" into the timetable, thus the following discussion focuses on the other 3 indicators.

\section{Journey Time per Vehicle Mile (JTVM)}

Journey time per vehicle mile has been monitored on the network shown in Figure 3 for over a decade by using the moving observer method. Survey staff are required to drive inbound along predefined radial routes and around the Nottingham Ring Road between 7am and 10 am Monday to Friday. Each route is surveyed on at least two different dates in the neutral autumn months.

A GPS recorder is used to collect the positional data which is then analysed using a bespoke ACCESS application to generate journey times on each segment of each route. 2010 has been identified as the appropriate baseline year as this is the year prior to the introduction of the WPL.

Figures 3 summarise the data available to date for this indicator. JTVM fell significantly in 2011 and then rebounded in 2012 to pre-recession levels. It should be noted that 2010 was the $1^{\text {st }}$ year since 2005 that JTVM had increased and thus can be seen as a "blip".

Nevertheless initial results from the alternative data sources confirm that this is not an error 
therefore at present it will still be used as the baseline year. It should be noted that prior to 2010 the monitoring was split between spring and autumn over an academic year; it is not thought that the change to monitoring in the autumn has had significant statistical effect.

Figure 3 Journey Time per Vehicle Mile: Time Series (moving observer data)

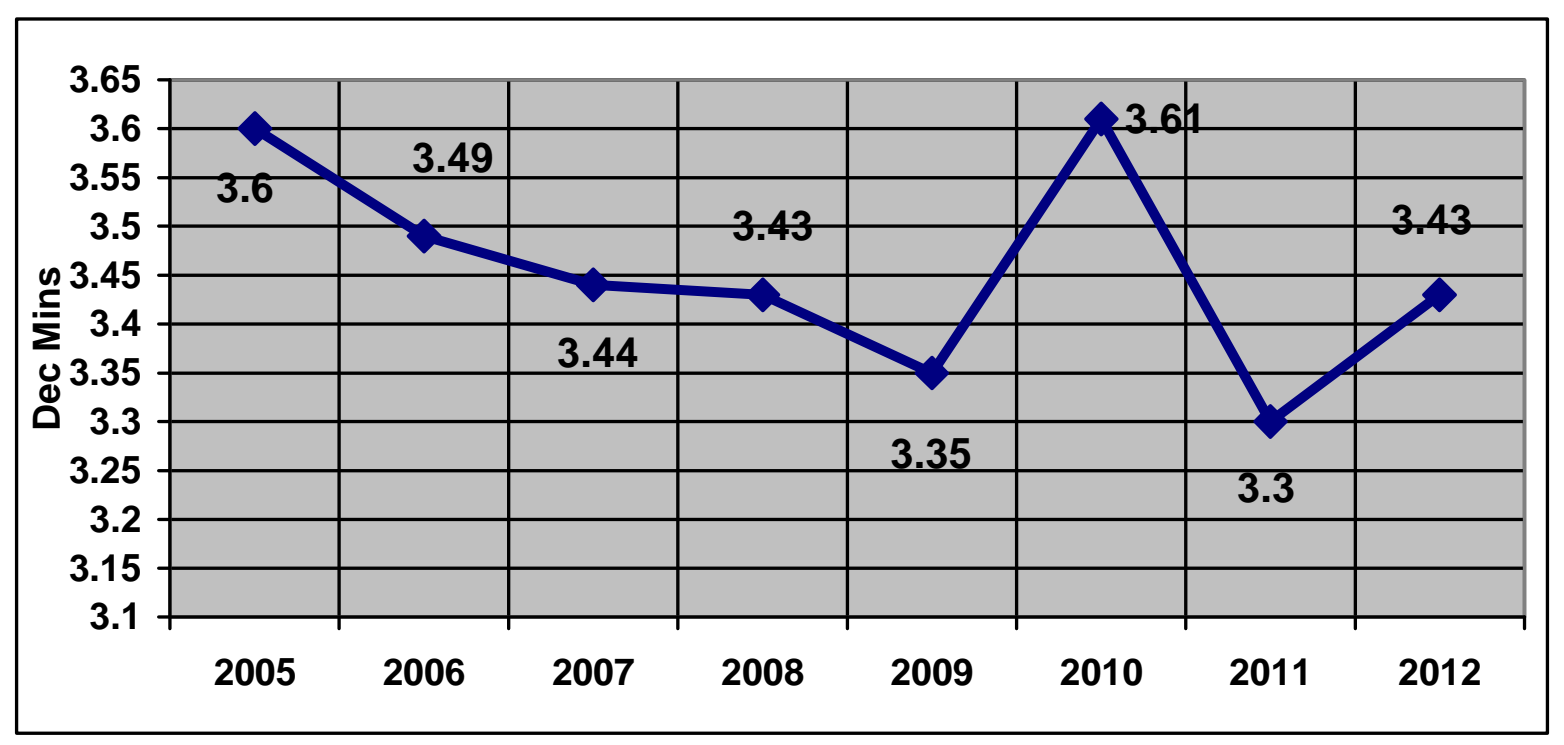

It can be concluded that there is no evidence to date to suggest that WPL has resulted in a reduction in congestion based on JTVM. It is however too early to conclude that it will not, in time, have a positive effect even as a stand-alone transport demand management measure.

\section{Area wide traffic mileage}

Area wide traffic mileage is a measure of how much traffic uses the specified road network in a calendar year and is calculated using automatic and manual traffic counts across the conurbation. As can be seen from Table 6, this fell between 2010, the base year, and 2011 possibly due to the economic conditions. As 2012 data is not yet available it is not possible to draw any conclusions as to whether WPL has affected this as it was not introduced until October 2011.

Table 6: Area wide traffic mileage 2005-2011

\begin{tabular}{|l|l|l|l|l|lr|r|}
\hline Area/Yr & $\mathbf{2 0 0 5}$ & $\mathbf{2 0 0 6}$ & $\mathbf{2 0 0 7}$ & $\mathbf{2 0 0 8}$ & $\mathbf{2 0 0 9}$ & $\mathbf{2 0 1 0}$ & $\mathbf{2 0 1 1}$ \\
\hline Greater Nottingham & 1881 & 1880 & 1878 & 1837 & 1847 & 1838 & 1805 \\
\hline City & 665 & 667 & 662 & 650 & 658 & 655 & 648 \\
\hline
\end{tabular}

\section{The percentage of cars with one occupant}

The percentage of cars with one occupant is calculated from data generated from annual modal share surveys carried out at fourteen sites on radial routes as they cross a nominal cordon line into Nottingham in the AM peak period. A manual modal share survey is conducted at each site on the cordon in the spring or autumn, in the AM peak period (7am$10 \mathrm{am}$ ) for inbound traffic. A classified traffic count is augmented by occupancy surveys of buses, trams and multiple occupancy cars (i.e. the occupancy of all cars with more than 1 occupant) crossing the cordon line. The total people movement by mode can then be 
calculated and thus the percentage of travel by each mode. The number of single occupancy cars can be calculated by subtracting those observed with two or more occupants from the total number of cars recorded in the classified count. A decrease in this percentage i.e. an increase in average occupancy is seen as a positive outcome. The percentage of cars with one occupant fell from the 2010 baseline year level of $82 \%$ to $80.6 \%$ in 2011 before rebounding in 2012 to $82.5 \%$. This pattern replicates that observed with JTVM data indicating at first a positive movement of the indicator followed by deterioration in 2012. However this change is very small and could be covered by margins of survey error.

At present none of the above indicators used to monitor this objective show any evidence that the WPL is having an impact on congestion. The pattern across the three years, 2010 to 2012 shows a general positive movement in modal share and journey time indicators in 2011 followed by a deterioration in 2012 . The reasons for this are not fully understood at this time and further research is required, however economic conditions may be playing a role as observed in Perth.

\subsection{Objective 5: Enhance the attractiveness of Nottingham as a location for business investment.}

Along with Objective 1, this is considered a critical objective, as those who oppose with the WPL often cite the extra cost on business the WPL brings as a factor which is likely to damage the economy. Monitoring this objective is seen as a major challenge.

The indicators can be split into macro economic indicators for which data is currently available albeit several years in arrears and micro-economic indicators for which data is not yet available. It is an important aim of the ongoing monitoring project to design and act on a methodology for collecting the micro economic data.

The macro economic indicators reviewed are as follows, in all cases the base line year will be 2010 although where possible this has been contextualised via a time series:

Number of jobs - This indicator is based on official Office for National Statistics (ONS) data. Up to 2008 the data was collated from the Annual Business Inquiry Survey (ABI). However from 2008 onwards the ONS replaced the $A B I$ with the Business Register and The 2005 -2007 ABI figures have been corrected to reflect the differences between 2008 values produced by the two methods.

- Business births and deaths - Net VAT registrations and de-registrations from the ONS Business Demography, an annual publication.

- Level of investment enquiries to the Nottingham City Council's Inward Investment Team.

\section{The number of jobs based in the Nottingham City Area}

Table 7 and Figure 4 present a time series of data showing the number of jobs in Nottingham, other similar "comparator" English cities and England as a whole. The official data from the ONS shows the number of jobs in Nottingham increased by $2.8 \%$ between September 2010 and September 2011 which compares favourably with the situation for both comparator cities and England as a whole. 
Table 7: Number of jobs in Nottingham, other similar Cities and England,

\begin{tabular}{|c|c|c|c|c|c|c|c|c|}
\hline \multirow[b]{3}{*}{ City } & \multicolumn{7}{|c|}{ Year } & \multirow{3}{*}{$\begin{array}{c}\text { \%chang } \\
\text { e } 2010- \\
11\end{array}$} \\
\hline & \multicolumn{3}{|c|}{$\begin{array}{c}\text { Annual Business Inquiry } \\
\text { adjusted to BRES }\end{array}$} & \multicolumn{4}{|c|}{ BRES } & \\
\hline & 2005 & 2006 & 2007 & 2008 & 2009 & 2010 & 2011 & \\
\hline Nottingham & 187774 & 186149 & 183306 & 184500 & 188500 & 193900 & 199300 & 2.8 \\
\hline Sheffield & 255917 & 253175 & 252058 & 250900 & 243500 & 240300 & 237400 & -1.2 \\
\hline Bristol & 233270 & 233474 & 233474 & 234700 & 233500 & 239500 & 230900 & -3.6 \\
\hline Leicester & 161877 & 162487 & 161573 & 158100 & 156300 & 158600 & 154900 & -2.3 \\
\hline $\begin{array}{l}\text { Newcastle up on } \\
\text { Tyne }\end{array}$ & 190516 & 184017 & 177619 & 179600 & 169000 & 169000 & 172800 & 2.2 \\
\hline $\begin{array}{l}\text { Nottingham (City } \\
\text { Council Adjusted } \\
\text { figures) }\end{array}$ & 187774 & 186149 & 183306 & 190500 & 183100 & 183000 & 180200 & -1.5 \\
\hline England & 23164458 & 23044634 & 23261934 & 23331300 & 22670400 & 23085300 & 23058900 & -0.1 \\
\hline
\end{tabular}

Source: Nottingham City Council 06/06/2013

Figure 4: Number of jobs in Nottingham, other similar Cities and England 2005-11

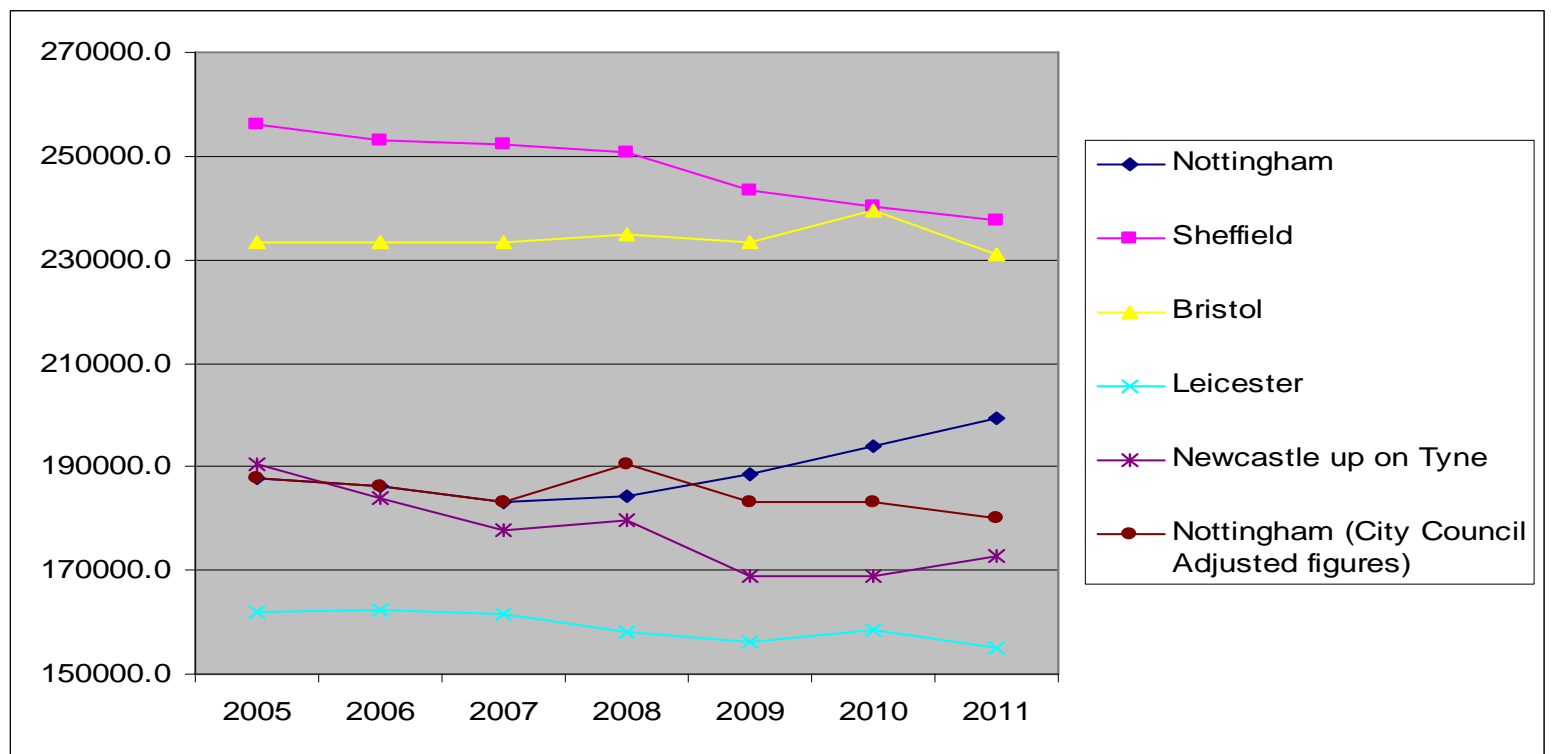

However, one must question why Nottingham shows such a positive upward trend while other similar cities suffered a reduction in jobs in the same period during which the national economy was in recession. A more detailed analysis of this data carried out by Nottingham City Council, which takes into account several organisations that have chosen to register all their national employment in Nottingham in recent years, has adjusted the ONS figure downwards to compensate for this. This shows a more realistic trajectory as can be observed in Figure 4. Furthermore the employment and unemployment data does not support the strong growth in jobs in Nottingham suggested by the ONS jobs data.

Unfortunately as a similar adjustment cannot be made for the comparator data it should be noted that the comparison is not like with like. However there is some evidence to suggest that the phenomena of national employers registering all their employment in one city is less pronounced in the comparator cities than it is in Nottingham.

Firstly the trajectory of the time series appears intuitively to be correct and more closely matches that of England as a whole with a decline in job numbers following the financial 
crisis and subsequent recession in 2008-2009. As it is an issue surrounding how jobs are allocated, the figures for England remain the same and thus form a reliable reference point.

Secondly, City Council's adjusted figures match the above pattern much better which in its self suggests a valid comparison.

Assuming that one accepts that Nottingham City Council's revised jobs figures for Nottingham is more accurate than those contained in the official ONS figures then Nottingham saw a 1.5\% reduction in jobs between 2010 and 2011. The England figure, a small rise of $0.1 \%$, is a poor yardstick to measure Nottingham's performance since the business demographics of a core City are very different to that of England as a whole which is heavily skewed by London and the South East. A fairer benchmark is the data for other similar sized cities. As Table 7 demonstrates, of the five Cities, Nottingham is second only to Sheffield in respect to minimising job loss between 210 and 2011.

Whichever version of the Nottingham ONS data is considered, all the available data suggests that Nottingham has faired no worse in terms of job losses than other similar cities and it is possible to conclude that, to date, there is no evidence to suggest that the introduction of WPL has resulted in any negative impact on the number of jobs based in Nottingham.

\section{Business births and deaths}

The business births and deaths are based on the balance of VAT registrations each year (as used in London). As it does not take into account the size of the employer and will miss expansions and contractions of major employers it can be considered as indicative of general economic health rather than being of use as a direct outcome from the WPL (most of VAT registered employers will be exempt from WPL by virtue of having less than 11 workplace parking places).

Table 8 and Figure 5 demonstrate that the balance of VAT registrations is negative for Nottingham and the other comparator areas in the baseline year of 2010. All areas improve in 2011, however only Nottingham and Sheffield remains marginally negative. Nottingham is thus lagging behind in its recovery from the recession.

Table 8 Business births and deaths: A summary for 2010, i.e. the baseline year

\begin{tabular}{|c|c|c|c|c|c|c|c|c|}
\hline \multirow[b]{2}{*}{ Area } & \multicolumn{4}{|c|}{2010} & \multicolumn{4}{|c|}{2011} \\
\hline & 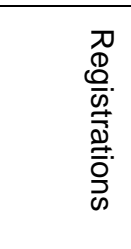 & 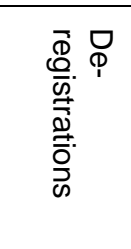 & 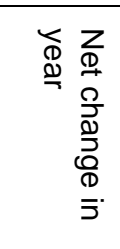 & $\begin{array}{l}\text { Net } \\
\text { change in } \\
\text { year per } \\
10,000 \\
\text { population } \\
16+\end{array}$ & 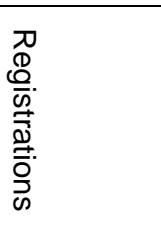 & 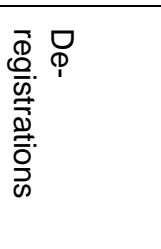 & 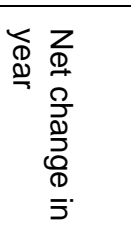 & $\begin{array}{l}\text { Net change } \\
\text { in year per } \\
10,000 \\
\text { population } \\
16+\end{array}$ \\
\hline Nottingham & 805 & 970 & -165 & -6.4 & 935 & 955 & -20 & -0.8 \\
\hline $\begin{array}{l}\text { Greater } \\
\text { Nottingham }\end{array}$ & 1,840 & 2,185 & -345 & -7.9 & 2,030 & 2,020 & 10 & 0.2 \\
\hline $\begin{array}{l}\text { East } \\
\text { Midlands }\end{array}$ & 14,325 & 19,545 & $-5,220$ & -6.6 & 16,055 & 15,150 & 905 & 2.4 \\
\hline England & 207,520 & 219,920 & $-12,400$ & -2.9 & 232,460 & 202,365 & 30,095 & 7 \\
\hline Bristol & 1,725 & 1,645 & 80 & 2.2 & 1,975 & 1,480 & 495 & 14.2 \\
\hline Newcastle & 725 & 815 & -90 & -3.7 & 895 & 775 & 120 & 5.2 \\
\hline Sheffield & 1,440 & 1,860 & -420 & -9.1 & 1,595 & 1,730 & -135 & -3 \\
\hline Leicester & 1,040 & 1,270 & -230 & -9.5 & 1,240 & 1,075 & 165 & 6.3 \\
\hline
\end{tabular}

Source: Nottingham City Council 06/06/2013 
Figure 5 Trends in NET VAT registrations year on year change 2004 - 2011

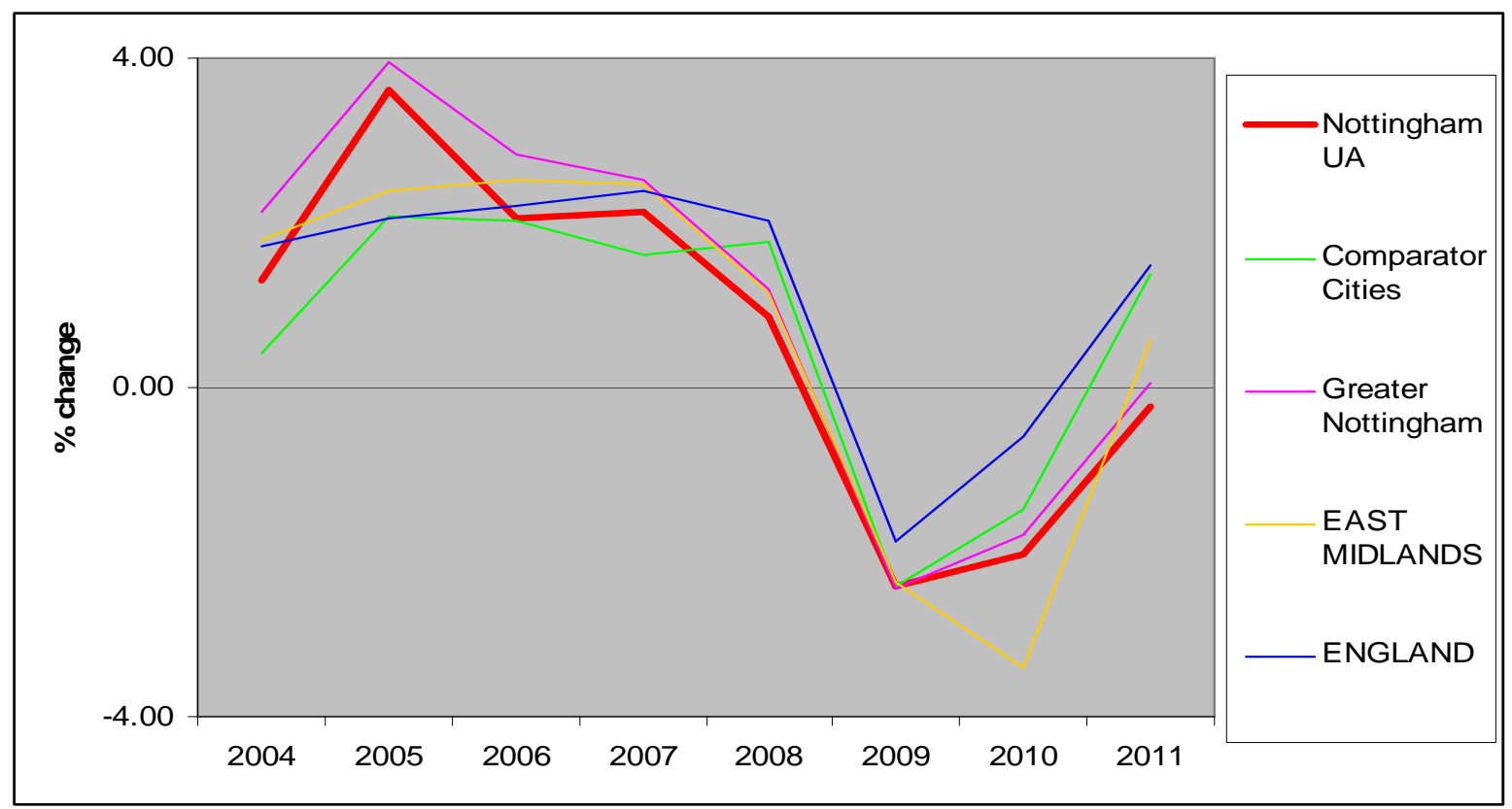

Source: Nottingham City Council 06/06/2013

Nottingham City Council's Transport Strategy Team considers that Nottingham often lags behind other areas in times of economic recovery due to a more conservative view of risk amongst Nottingham's business community. If so the question is therefore; is the prospect of WPL exacerbating this conservatism and putting businesses off starting up in Nottingham? If this is the case, this must be a view based on lack of understanding of the scheme as most businesses won't be impacted as discussed above.

On balance it is possible but unlikely that the above slow recovery in business VAT registrations is due to the implementation of the WPL. However additional years' data are required to confirm this view.

\section{Level of inward investment enquiries to Nottingham City Council}

Data from the Inward Investment team which tracks the number of enquiries concerning investing in Nottingham and those which then go on to actually invest shows that 2012/13 was a bumper year for both the level of enquiries and the number of successes moves to the City and subsequent job creation. However it cannot be assumed that the level of inquiries to Nottingham City Council necessarily reflects investment levels as a whole and thus this indicator must be used as complementary evidence to support or dispute conclusions drawn using more comprehensive macro economic indicators. Table 9 shows this data.

Table 9: Enquiries to the Inward Investment Team and subsequent successes

\begin{tabular}{|l|l|l|l|}
\hline Year & Enquiries & No. of successes & Jobs created \\
\hline $2008 / 09$ & 91 & 3 & 360 \\
\hline $2009 / 10$ & 156 & 5 & 85 \\
\hline $2010 / 11$ & 110 & 2 & 85 \\
\hline $2011 / 12$ & 146 & 5 & 65 \\
\hline $2012 / 13$ & 175 & 9 & 1100 \\
\hline
\end{tabular}

Source: Nottingham City Council 10/05/2013 
Although the location of a major retail distribution centre in the north of the City is partially responsible for this, it is only 1 of 9 successes. This would tend to confirm the above ascertation that Nottingham is recovering successfully from recession albeit perhaps more slowly than other areas. It will be interesting to see if the 2012 job figures and VAT registrations, neither of which are available until the autumn, reflect this trend.

\section{Concluding comments}

The Nottingham WPL scheme is the first of its kind in the UK. The outcomes from this scheme and the public transport improvements which it makes possible, by part funding, may determine if the WPL option is adopted by other UK cities over time and thus becomes a main steam option for funding large scale public transport improvements.

Existing literature points to a reduction in levels of congestion without a negative impact on business investment being of paramount importance to the schemes acceptance.

Literature indicates that the Australian parking space levy schemes have had a positive effect by encouraging mode switch to public transport, this is especially so in Perth. There is also evidence to show that this has been achieved without negatively impacting on the local economy.

However, because of cultural, geographic and economic differences it is not possible to conclude from the literature that the outcomes in Nottingham will be similarly positive.

Nottingham differs from the Australian examples in that it is located in close proximity of competitor cities and evidence from literature shows that acceptance by local business and the public is also a barrier to future implementation of WPL schemes. Therefore a thorough evaluation of its performance is essential if these barriers are to be overcome and other schemes introduced.

In its first year of full operation the WPL has raised £7millon of hypothecated revenue for public transport improvement. While the data from Nottingham to date suggests that, as yet, the scheme has had minimal impact on levels of congestion in the City, the evidence from macro economic indicators is demonstrating that Nottingham has faired no worse than other similar sized UK cities since the chosen base year for WPL monitoring, 2010. It should be noted that although the WPL has only been fully operational for a year, the business community has been aware that it was going to be implemented since 2010 and thus it is possible that any negative economic impact has had 3 years to take effect. This consideration increases confidence that the WPL is not having a negative effect on the macro economic indicators presented in this paper.

It is important to note that of the overall package of transport interventions that will take place in Nottingham between 2010 and 2015, only the WPL itself is currently in place and while it is proposed that even as a standalone measure the WPL will have a positive impact on some of the scheme objectives, the main benefits may not be realised until all the interventions which the WPL part funds are in place.

Therefore, considering the above it is thus perhaps not too surprising that there is, as yet, little impact on congestion.

While it is desirable to await further years data to confirm conclusions regarding the WPL's effect on the key outcomes for objectives 1 (congestion constraint) and 5 (inward investment), there is evidence of positive changes in employer behaviour and also the supply of Workplace Parking Places. Take up of travel planning has increased by $1.7 \%$ since 2010 as has the implementation of parking management schemes which seek to pass on the cost of the WPL to employees. These now cover $36 \%$ of Workplace Parking Places. Conversely 
there is evidence that the number of workplace parking places has fallen by $18 \%$ following the introduction of WPL. Furthermore, the WPL scheme has operated smoothly in its first year with no legal challenges and $100 \%$ compliance from WPL liable employers.

\section{References}

Burchell, J. and Ison, S., 2012, Employers Attitudes To The Workplace Parking Levy: A Case Study of Nottingham, UK, 92nd Annual Meeting of the Transportation Research Board, TRB, 09-0249, 12 Washington DC, USA.

Cabinet Office, 2013, Red Tape Review Website, [online], available on line at: http://www.redtapechallenge.cabinetoffice.gov.uk/2011/12/road-transport-announcement/ [Accessed 13/06/2013]

Core Cities, Passenger Transport Executive Group and Yorkshire Forward, 2006, How does transport influence business investment in the city regions, [online], Report into research carried out by GVA Grimley sponsored by Core Cities, Passenger Transport Executive Group and Yorkshire Forward, available at: http://www.pteg.net/NR/rdonlyres/D9B84F59B9E3-445B-91EE-14362CBA6447/0/GVA transport and business 200611.pdf [accessed 14/04/2013].

Department for Planning and Infrastructure (DPI), 2007, Review of Perth Parking Policy [available online], Sinclair Knight Merz for DPI: Perth: Department for Planning and infrastructure. Available on line at:

www.transport.wa.gov.au/mediafiles/regional parkingpolicy.pdf [accessed 21/05/2013].

Department of the Environment, Transport and the Regions (DETR), 1998a; A new deal for transport: better for everyone, The Government's White Paper on the Future of Transport. London: The Stationery Office. Available on line at:

http://www.nottinghamcity.gov.uk/CHttpHandler.ashx?id=2510\&p=0 [accessed 03/05/2013]

Department of the Environment, Transport and the Regions (DETR), 1998b. Breaking the Logjam: The Government's consultation paper on fighting traffic congestion and pollution through road user and workplace parking charges. London: The Stationery Office. Available online at: http://www.nottinghamcity.gov.uk/CHttpHandler.ashx?id=2511\&p=0 [accessed 03/05/2013].

Department of Transport (DoT), 2012. Licensed parking in Perth: a guide for commercial property owners about licensing of parking bays for 2012-13, Perth, Australia: Department of Transport, The Government of Western Australia. Available online at:

http://www.transport.wa.gov.au/mediaFiles/DOT I LicPark.pdf [accessed 30/04/2013].

Deran, E., 1965, Earmarking and Expenditures: A Survey and a New Test, National Tax Journal,18:354-361

Dodd B., 2007, The Proposed Nottingham Workplace Parking Levy, Report of the Public Examination. [online], The UK Planning Inspectorate available online at http://www.nottinghamcity.gov.uk/CHttpHandler.ashx?id=2681\&p=0 [accessed 05/05/2013]

East Midlands Development Agency (EMDA), 2007, Economic Costs of Congestion in the East Midlands, Nottingham: Atkins for the East Midland Development Agency.

Enoch, M.P., 2001, Workplace parking charges Down Under, Traffic Engineering and Control November 2001, 357-60. 
Enoch, MP, and Ison, S.G., 2006, Levying Charges On Private Parking: Lessons from Existing Practice, World Transport Policy and Practice, 12(1), 5-14.

Frost, M.W. and Ison, S.G., 2008, Implementation of a Workplace Parking Levy, Lessons from the UK, 88th Annual Meeting of the Transportation Research Board, TRB, 09-0249, 12 Washington DC, USA, 15th January 2008.

Hamer, P., Currie, G. and Young, W., 2009, Exploring travel and parking impacts of the Melbourne CBD parking levy, Australian Transport Research Forum 2009, $32^{\text {nd }}$ meeting, Auckland, New Zealand.

Ison, S. and Wall, S., 2002, Attitudes to traffic related issues in urban areas of the UK and the role of workplace parking charges, Journal of Transport Geography, 10(1), $21-28$.

Ison, S. and Wall, S., 2003, Market and non-market based approaches to traffic related pollution: the perception of key stakeholders, International Journal of Transport Management, $1,133-143$.

Litman, L., 2011 Parking Taxes Evaluating Options and Impacts, [online], Melbourne: Victoria Transport Policy Institute, available online at: http://www.vtpi.org/parking tax.pdf [accessed 30/12/2012].

Martin, S., 2012,_Stifling Success: Congestion charges and infrastructure delivery [online], Melbourne: Committee for economic development of Australia, Available at http://ceda.com.au/research-and-policy/research/2012/04/stifling-success [accessed 24/05/2013]

New South Wales Ministry of Transport, 2003, Parking Space Levy Review: Improving public transport, Sydney: New South Wales Ministry of Transport.

Nottingham and Derby Chamber of Commerce, 2012 Unpublished e-survey summarised and available at http://www.thisisnottingham.co.uk/Firms-look-leaving-city-parking-levy/story17018942-detail/story.html [accessed 04/06/13].

Nottingham City Council (NCC), 2005, Workplace Parking Levy Economic Impact, PwC for Nottingham City Council, [online] Nottingham: Nottingham City Council, available online at: http://nottinghamcity.gov.uk/CHttpHandler.ashx?id=2492\&p=0 [accessed 20/05/2013].

Nottingham City Council (NCC), 2008. Workplace Parking Levy Business Case [online], Nottingham: Nottingham City Council, April 2008, available at:

http://www.nottinghamcity.gov.uk/CHttpHandler.ashx?id=2672\&p=0 [accessed 04/06/2013].

Nottingham City Council (NCC), 2012. WPL - Employer Handbook. [Online] Nottingham: Nottingham City Council, available at:

http://www.nottinghamcity.gov.uk/CHttpHandler.ashx?id=27158\&p=0 [Accessed on 11/05/13].

Nottingham Post, 2012, Levy may see us move on after 27 years, claims depot manager, [online] Nottingham: Nottingham Post, available on line at

http://www.thisisnottingham.co.uk/Levy-27-years-claims-depot-manager/story-15678012detail/story.html [accessed 03/12/12]

Nottingham City Council (NCC), 2013. Nottingham Local Transport Plan 2011 to 2026.

[Online] Nottingham: Nottingham City Council , available at: 
http://nottinghamcity.gov.uk/index.aspx?articleid=24051 [accessed on 14/06/13].

Richardson, E., 2010, Extracting Maximum Benefit From Parking Policy - 10 Years Experience In Perth, Australia, European Transport Conference 2010,38 ${ }^{\text {th }}$ edition, Glasgow, Scotland, UK October 2010, London: The Association for European Transport.

Smyth, A. and Christodoulou, G., 2010, Making Tracks: Transport for 21st Century Business, European Transport Conference 2010, 38 ${ }^{\text {th }}$ edition, Glasgow, Scotland, UK October 2010, London: The Association for European Transport.

Smyth, A., Christodoulou, G. and Newman, P., 2010a Smart Connections: The essential role of transport for borderless business, [online] London: Invest Thames Gateway, available online at http://i-dmc.co.uk/resources/documents/ITG TL 006 spreads.pdf [accessed on 05/06/2013].

State of Western Australia, 2009, The Evolving City: An atlas of change in the city of Perth 1990-2007, [online], Perth: Department of Planning,

Western Australian Planning Commission and the City of Perth, Available at: http://www.cityofperth.wa.gov.au/getfile/20635.pdf [accessed 05/05/2013].

State of Western Australia, 2012, Perth Parking Management Act 1999: Perth Parking Policy 2012 [online], Perth: State of Western Australia, available on line at:

http://www.transport.wa.gov.au/mediaFiles/DOT R ParkPol.pdf [accessed 05/06/2013].

State Revenue Office Victoria, 2012, Congestion Levy Overview web page, [online]

Melbourne, Australia: State Revenue Office Victoria, available online at:

http://www.sro.vic.gov.au/SRO/sronav.nsf/childdocs/-

3A87315B22BC23FFCA2575A100441F59-EFC160ABBE873990CA2575B70020FC3B-

F47D8E52D98A8D12CA2575A100444BBE [accessed 30/04/2013]

Thorpe, N., Hills, P., Jaensirisak, S., 2000, Public attitudes to TDM measures: a comparative study, Transport Policy, 7(4), 243-257.

Transport Act 2000, Chapter 38 Part III Chapter II [online], available at http://www.legislation.gov.uk/ukpga/2000/38/part/II/chapter/ll [accessed 25/05/2013].

Transport for London (2008), Central London Congestion Charge: Impacts Monitoring Sixth Annual Report: July 2008, [online] City of London: Transport For London. Available at http://www.tfl.gov.uk/assets/downloads/sixth-annual-impacts-monitoring-report-2008-07.pdf [accessed 10/05/2013].

Transport for New South Wales, 2013, Parking Space levy web page, [online] Sydney: Transport for New South Wales, available at: http://www.transport.nsw.gov.au/content/parking-space-levy [accessed 30/04/2013].

TransLink, 2012, Parking Tax FAQ, [online] Vancouver: Trans Link, available online at: http://www.translink.ca/en/About-Us/Taxes/Parking-Tax/FAQs.aspx [accessed 30/04/2013].

Westcott, S., 2012, Anger at Stealth Tax on Parking at Work, [online], Journalistic Article on Express.co.uk website, available at: http://www.express.co.uk/posts/view/312004/Anger-atstealth-tax-on-parking-at-work [accessed 03/06/13].

Workplace Parking Levy (England) Regulations, 2009, [online], available on line at: http://www.legislation.gov.uk/uksi/2009/2085/contents/made [accessed 10/04/13]. 